\author{
2 \\ ELK \\ Asia Pacific Journals \\ www.elkjournals.com
}

\title{
A STUDY ON IMPACT OF GREEN MARKETING TOOLS' ON CONSUMERS' GREEN PURCHASE INTENTIONS AND BUYING BEHAVIOR IN URBAN PUNJAB
}

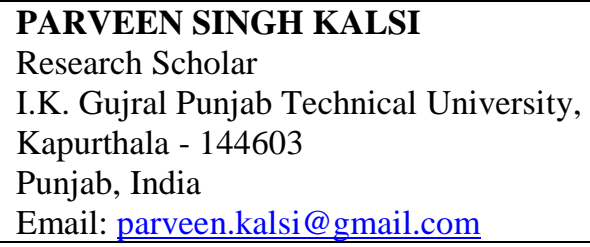

\author{
DR. INDERPAL SINGH \\ Associate Professor \\ KCL Institute of Management \& Technology, \\ Jalandhar \\ Punjab, India \\ Email: arora inderpal@yahoo.co.in
}

\begin{abstract}
The present study determines the impact of Green Marketing Tools' on consumers' Green Purchase Intentions and Buying Behavior (i.e. Green Purchase Behaviour) in urban Punjab, India. This research utilizes survey based method to validate the theoretically framed hypotheses. A structured questionnaire was used to solicit and gather responses from 538 respondents from the selected cities of the state of Punjab, India. The primary data collected was analysed using SPSS 21.0 with statistical measure of regression to generate the results. The analysis of this study reveals that Green Marketing Tools' demonstrates a direct influence on consumers' Green Purchase Intentions and Green Buying Behaviour (i.e. green purchase behaviour), respectively. Further, the novelty of the present research is the findings that Green Purchase Intentions fully mediates the relationship of Green Advertising and Green Price, respectively with Green Purchase Behaviour; and partially mediates for Green Product Availability, Green Product \& Brand and Eco-labels. The findings can be used by business organizations \& marketers to develop marketing strategies to inculcate favorable purchase intentions among consumers' for pertinent green purchase behaviour.
\end{abstract}

Keywords: Eco labels, Green Advertising, Green Price, Green Marketing, Green Product Availability, Green Product \& Brand, Green Marketing Tools', Green Purchase Behaviour, Green Purchase Intentions, Mediation

\section{INTRODUCTION}

Global indicators confirm that world posses a strong urge for sustainable development as the natural resources are continuously depleting and environmental piousness is getting reduced. Thus, business 
ISSN 2349-2317 (Online); DOI: 10.16962/EAPJMRM/issn. 2349-2317/2018; Volume 9 Issue 4 (2018)

organizations \& marketers have

meaningfully affirmed the proenvironmental concerns as a strategic concern for sustainable working of the businesses (Menon \& Menon, 1997; Polonsky \& Kilbourne, 2005) and contemporary businesses to remain profitable in this multifaceted complex business environment has regarded Green Marketing as one of the prominent measure (Pujari \& Wright, 1996; Kassaye, 2001). Consumers perceptive towards the environmental upheaval possess relevant environmental knowledge and continuously update themselves to make relevant and apt environment friendly purchase decisions (Laroche \& Barbaro-Farleo, 2001).

\subsection{Green Marketing}

Stanton \& Futrell (1987) referred "green or environmental marketing as actions intended to replace current needs and wants with minimal harmful impact on our environment". According to Hartmann \& Ibáñez (2006) "green marketing generally focuses on the efficiency of cognitive persuasion strategies, and believes that the consumer's high involvement concerning environmental issues is an effect of growing environmental knowledge".

\subsection{Green Marketing Tools'}

In the following sub-sections various green marketing tools' have been elaborated with their perspective:

\subsubsection{Green Advertising}

Zinkhan \& Carlson (1995) defined "green advertising as the appeals that try to fulfill consumers' needs and aspiration regarding to environmental concern and health issues from different perspectives including ecology, sustainability, and pollution-free messages". Environmental content in advertisements increases customers' inclination and preference towards likewise advertisements (Hawkins et al., 1998). Chan (2004) and D'Souza et al. (2006) affirmed that marketers are liable to advertise environment or green information, as the customers search for more reliable and genuine advertised information to make pertinent purchase decisions. Researchers like Mathur \& Mathur (2000) and Habib et al. (2010) considered and recommended that message being exposed through green advertising is more trustworthy, thus consumers after viewing the message becomes more inclined towards green products. However, the advantages of green 
ISSN 2349-2317 (Online); DOI: 10.16962/EAPJMRM/issn. 2349-2317/2018; Volume 9 Issue 4 (2018)

advertising are contentious to some extent (Pfanner E., 2008) because of astounding language \& vague information (Easterling et al., 1996; Polonsky et. al., 1997) due to which sceptical attitudes formed by consumers' towards green advertising (Crane A., 2000)

\subsubsection{Green Price}

Consumers possess willingness to pay for green products (Chyong et. al., 2006) and (Laroche et al., 2001) affirmed that the frequency of individuals had increased who are ready to shell out premium price for green products. Similarly, $81 \%$ of Indian consumers are willing to pay more for ecofriendly products than their counterparts, revealed by a global study of UL (in 2013) and it ranks India high on prioritizing product quality (Web Reference, 2014). However, several researchers indicated that the consumers portray sceptical purchase behaviour premium priced green products (Blend \& van Ravenswaay, 1999; D'Souza et al., 2006).

\subsubsection{Green Products \& Brand}

According to Mishra \& Sharma (2010), "green products are products which are originally grown with natural ingredients containing recycled contents and non-toxic chemicals which do not pollute the environment, as they are recyclable, reusable and biodegradable". Consumers' familiarity with the green product and its brand is necessary as otherwise they would be reluctant to purchase it (Glegg et al., 2005). Thus, business organizations comprehensively use marketing promotional campaigns regarding green perspective to amplify their green brand's knowledge among the consumers to nurture organization's better image (Adkins, 2004).

\subsubsection{Green Products Availability}

Green product availability refers to the comprehensive distribution ability of the business organization to ensure the timely availability of the green product at the right time at the right place to provide convenient accessibility to the customer to make relevant product purchase. At times, even the customers with high motivation are not able to translate their favourable green purchase intention into like purchase action due to low availability of green products (Vermeir and Verbeke, 2004).

\subsubsection{Eco labels}


ISSN 2349-2317 (Online); DOI: 10.16962/EAPJMRM/issn. 2349-2317/2018; Volume 9 Issue 4 (2018)

Rex \& Baumann (2007) indicated "ecolabels as a tool for consumers to facilitate making decision for select environmentallyfriendly products also enable them to know how products are made". Researchers in the past endeavoured their research on eco labels to identify the proficient preposition to align them meaningfully with the consumers' green purchase behaviour (D'Souza et. al., 2006; Sammer \& Wüstenhagen, 2006), however others through their research inferred that eco labels alone cannot instinctively push them for green purchase behaviour (Leire \& Thidell, 2005). Further, several researchers in the earlier period examined the relationship between eco labels and consumer's intention \& behaviour to purchase green products (Whitson \& Henry, 1996; D'Souza, 2004). Nik Abdul Rashid (2009) believe that eco label are efficient in communicating with consumers regarding the environmental perspective of their purchase decisions, further as per the research study revealed that eco label exhibited a positive effect on the relationship of green product and consumer's intention. However D'Souza (2004) deduced a minute impact of eco label information on consumers' green purchase intentions. Nevertheless, eco labels for organizations are viewed as a significant tool to impact consumers purchase patterns (Thorgersen, 2002; Nik Abdul Rashid, 2009).

\subsection{Green Purchase Intentions}

Green Purchase Intentions are the behaviour intentions which provide an individual's enduring vigour to perform the likewise behaviour Ng \& Paladino (2009) and according to Ramayah et. al. (2010) it is the strength of the mind to operate in a defined manner. Further, Nik Abdul Rashid (2009) affirmed intentions as the likewise chance and readiness of a customer which provide inclination towards green products over traditional non-green products while making relevant purchase decisions.

\subsection{Green Buying Behaviour}

Purchase Behaviour involves two types of purchases i.e. "trial purchases" and "repeat purchases" (Schiffman \& Kanuk, 2008). Thus, for this study the purchase behaviour would include the consumers' evaluation of green product to ascertain favourable buying intentions and preferences towards significant repeat purchases. Further, Mainieri et al. (1997) expressed it as the 
process of buying and consuming products which are kind towards environmental considerations.

\section{REVIEW OF LITERATURE}

Chan (2004) found that print advertisements are more favored than broadcast advertisements for dissemination of environmental advertisements because of their pragmatic orientation. The statistical analysis of the research inferred that green purchase intention of Chinese consumers were significantly affected by factors such as perceived credibility of the claim, relevance of the advertised product to daily lives, education level and media type. D'Souza et. al. (2006) in their research inferred that consumers who are willing to buy green products are very inquisitive about environmental information on product labels; and are ready to accept green products even they are lower in quality as compared to non-green products. Gan, C. et. al. (2008) studied the factors which impacted the consumers' purchase behaviour towards green products and distinguished between the purchasers and non-purchasers. Higher price of green products negatively affected consumers purchase decisions and green labels did not catalyzed their purchase decisions. Nik Abdul Rashid (2009) inferred that experience of environment related endeavours increases the belief of Malaysian consumers to react positively towards ecolabels. Further, concluded that higher ecolabel awareness always lead towards stronger relationship between knowledge and purchase intention of products with progreen features. Saxena \& Khandelwal (2010) in their research elucidated that companies which offer green products certainly will earn a competitive edge over their rivals because of their green brand image. Drozdenko, R. et. al (2011) deduced that the customers were prepared to pay 9.5\% premium for 'green music player', $10.4 \%$ premium for the 'hybrid car'. The research also highlighted that because of tax incentives, the consumers (basically homeowners) were prepared to spend money for purchase of solar panels and green water heaters. Ishaswini \& Datta (2011) in their study concluded that there exists willingness among consumers to buy eco-friendly products but possess skeptical attitude towards price premiums. Khandelwal \& Bajpai (2011) in their study deduced a significant positive linear relationship between green advertising and purchase 
ISSN 2349-2317 (Online); DOI: 10.16962/EAPJMRM/issn. 2349-2317/2018; Volume 9 Issue 4 (2018)

intention. Rahbar \& Wahid (2011) in their research established no significant positive association for consumer's actual purchase behaviour was determined by eco-label and environmental advertisement, respectively. Ali \& Ahmad (2012) in their research revealed that the consumers have high positive attitude towards green products and are willing to purchase green products more often; however the green products must perform competitively similar as traditional products in terms of quality and price. Boztepe, A. (2012) explained that green purchase behaviour increases as environment consciousness, green product features, green promotion and green price increases. The results explained that environmental awareness, green product features, green promotion activities and green price positively affect the green purchasing behaviour of the consumers in Istanbul. Juwaheer T.D., et. al. (2012) inferred an overall positive correlation between effective green marketing strategies and customers' purchasing patterns for green products. The researchers indicated that the companies must utilize green marketing tools' such as green branding, eco-labeling and green packaging to encourage green consumption among consumers in
Mauritius. Veluri (2012) concluded that green brands were unable to generate hype among consumers. Ansar, N. (2013) concluded that environmental advertisements, price and ecological packaging were found to be positively related with green purchase intentions. Mahesh, N. (2013) inferred positive influence of reasonable prices, value for money prepositions, acceptable quality standards, environmental friendliness and food safety on the consumer's purchase intention for green products. Mehta, P. (2013) in her doctoral research identified that the consumers' beahviour towards green products was influenced by factors such as social influence, quality consciousness, health benefits, ecological concern, resource conservation consciousness, availability of green product, price consciousness, synthesized green product information and style orientation. Zhu, B. (2013) revealed that credibility of claim in green advertising and consumer attitude towards green advertising significantly influenced the consumer's purchase intention of green products. Agyeman, C. M. (2014) suggested that environmental concern, price and quality of the green product actually are crucial for likewise purchase of green 
ISSN 2349-2317 (Online); DOI: 10.16962/EAPJMRM/issn. 2349-2317/2018; Volume 9 Issue 4 (2018)

products. Delafrooz, N. et. al. (2014) in their research found that environmental advertisement showed the most significant influence on the consumers' purchase behaviour while eco-brand exhibited the least influence. Diglel \& Yazdanifard (2014) in their research suggested that consumers were motivated to purchase ecofriendly products from those organizations which exhibited green logo or image to generate trust among customers. Ahmad \& Thyagaraj (2015) in their study suggested that educating consumers' regarding environmental concern and guiding them towards self expressive benefits will definitely generate appropriate green purchase intentions. Ferraz, B. S. et. al. (2017) in their research study deduced a positive and direct relationship between intention and behaviour. Further, the research revealed that the Canadian students were ready to shell-out additional price for green product and were prepared to abandon traditional products to support environmental conservation than their Brazilian counterparts. Mamun, A. A. et. al. (2018) in their research found that the normative beliefs powered the readiness to shell-out money for green products. Further, the research exhibited significant positive effect of perceived behavioral control and readiness to shell-out money for green products on the payment behaviour.

\section{RESEARCH METHODOLOGY}

In the following sub-sections various aspects like need of the study based upon research gap, research objectives \& hypotheses of the study and other research methodology particulars have been detailed with their reasoning:

\subsection{Need of the study}

The researchers across the nation and globe have used individually or together the various tools' of green marketing measures in different time settings to elucidate the influence of green marketing measures (i.e. tools') on green purchase intentions or on green purchase behaviour. However till present, especially in a country like India where the pertinent selling and buying of green products at the national level has just started to increase from the nascent stage, very limited research has been carried out to measure the impact of green marketing tools' on purchase intentions and buying behaviour. Thus, there is a pertinent need to comprehensively synthesize the impact of green marketing tools' on consumers' green 
ISSN 2349-2317 (Online); DOI: 10.16962/EAPJMRM/issn. 2349-2317/2018; Volume 9 Issue 4 (2018)

purchase intentions and buying behaviour, which will certainly encourage the business organizations \& marketers to formulate strategies conducive to promote and enhance pro-environmental consumer behaviour, which will subsequently facilitate the consumers' to adopt green consumerism and related pro-green life styles for sustainable living across different boundaries. Therefore, the present research which aims at empirically analyzing the influence of green marketing mix tools' (i.e. green product \& brand, green price, green product availability, green advertising and ecolabels) on consumers' green purchase intentions and related purchase behaviour will help marketers to understand the buyer's paradox more comprehensively. Further, the analysis of mediation role of green purchase intentions on the relationship of green marketing tools' and green purchase behaviour will certainly elucidate the importance which the business organizations \& marketers must associate with marketing strategies to develop and nurture likewise purchase intentions among consumers for sustainable green purchase behaviour.

\subsection{Research Objective}

To assess the impact of green marketing tools' on consumers' green purchase intentions and buying behaviour.

\subsection{Research Hypotheses}

Based upon the review of literature and to fully accomplish the scope of the aforesaid narrated objective, the following hypotheses have been formulated:

H1: Green Marketing Tools' exhibit a direct significant impact on the consumers' Green Purchase Intentions.

H2: Green Marketing Tools' exhibit a direct significant impact on consumers' Green Purchase Behaviour.

H3: Green Purchase Intentions fully mediates the relationship between Green Marketing Tools' and consumers' Green Purchase Behaviour.

\subsection{Geographical Extent of Survey}

The current study is limited to the urban consumers in the state of Punjab. In order to enhance the feasibility of the primary research, two cities each having average literacy rate greater (Census, 2011 - Web Reference, 2014) than $75 \%$ were identified through draw of lots method which represented the three regions equally (i.e. Doaba, Majha and Malwa) from the state of 
ISSN 2349-2317 (Online); DOI: 10.16962/EAPJMRM/issn. 2349-2317/2018; Volume 9 Issue 4 (2018)

Punjab. Thus, the following narrated cities i.e. Jalandhar \& Hoshiarpur (from Doaba Region), Amritsar \& Gurdaspur (from Majha region) and Ludhiana \& Patiala (from Malwa region) were ascertained for data collection purposes.

\subsection{Sampling Unit \& Accessible Universe}

The present research is about the analysis of consumers' perception towards green marketing tools' and thereon to evaluate its impact on green purchase intentions and related purchase behaviour. Accordingly, for this research the sampling unit has been characterized as an urban consumer who has age greater than 18 (eighteen) years. Thus, the likewise accessible universe for this research encompasses all the urban consumers (in the selected six cities, two from each region / strata in the state of Punjab) who have age greater than 18 (eighteen) years.

\subsection{Questionnaire Preparation and Data}

\section{Collection}

This present study is principally based on the primary data gathered through respondents' responses through a structured questionnaire. The scale items to measure the 'green marketing tools' and its impact on consumers' purchase intentions and buying behaviour in urban Punjab' are based on the review of the literature. Table - 1 details the published review sources referred for questionnaire scale construction.

For the purpose of data collection, a total of 600 consumers were approached from the identified six cities of Punjab for soliciting their responses towards the structured questionnaire especially designed for this research study. In order to ensure that measurement error does not impact the research results, the questionnaires with missing responses were dropped. Likewise 62 questionnaires were discarded which have not been used for analysis.

\subsection{Data Analysis}

The software utility of SPSS version 21 has been used to analyse the primary data collected through the questionnaires for pertinent statistical analysis using regression.

\section{RESEARCH RESULTS}

In the following sub-sections hypothesiswise research results have been enumerated:

\subsection{Role of Green Marketing Tools' in influencing the consumers' green}


ISSN 2349-2317 (Online); DOI: 10.16962/EAPJMRM/issn. 2349-2317/2018; Volume 9 Issue 4 (2018)

purchase intentions and green buying behaviour

The role of green marketing tools' is determined using the following steps:

\subsubsection{Reliability of Data}

The Cronbach's alpha method is used to calculate the reliability of the scale. The calculated value of Cronbach's alpha is 0.821 , which is greater than the acceptable limit (Hair et. al., 2010). Hence, the achieved value confirmed the reliability of the scale.

\subsubsection{Factor Analysis:}

The pertinent application of factor analysis represented the KMO value as 0.794 , which is considered as adequate and considerable. Further, the Bartlett's test of sphericity reported chi-square value of 823.519 at 153 degrees of freedom for a significance value of $.000(\mathrm{p}<0.05)$, which is considered as significant and considerable. Hence, both the measures established the suitability and adequacy of data for the subsequent application of factor analysis. (Table - 2)

Factor analysis using principal component analysis method has been used. This method identifies the minimum or least number of factors which provide maximum variance in the data (Malhotra \& Dash, 2010). The results as represented in the corresponding table provide the information of communalities and initial eigen values of the variables. (Table - 3)

Only factors with eigen value greater than 1 have been retained and others have been discarded for further analysis. Five factors collectively contributed for a total variance of 64.461 percent. (Table - 4)

After determining the five factors with eigen values more than one which together generated a total variance equal to $64.461 \%$, the rotated component matrix using Varimax Rotation method with Kaiser normalization represented convergence in 9 iterations. The results, as categorized in the related table only detailed those statements which possess factor loading more than 0.50 to create latent variables (Malhotra \& Dash, 2010). (Table -5)

\subsubsection{Naming of the factors}

Output of the rotated component matrix guided the generation of five relevant factors, which hereon have been named. The following is the brief description of the five 
ISSN 2349-2317 (Online); DOI: 10.16962/EAPJMRM/issn. 2349-2317/2018; Volume 9 Issue 4 (2018)

factors proposed through factor analysis: (Table - 6)

Factor 1: Green Advertising: This factor enumerates the importance that green advertising certainly is helpful in promoting the green products. Further, it helps the customers to acquire knowledge and benefits of the green products over the non-green products. The factor generates a reliability value of 0.831 .

Factor 2: Green Price: This factor describes the effectiveness of price (i.e. green price) in generating the adequate uniqueness of the green products as compared to their counterparts. In general, the higher preposition of green price is acceptable by the customers because of the benefits of the green products. This factor scores reliability value of 0.795 .

Factor 3: Green Product Availability: This factor explains that green products' availability is crucial in generating the widespread coverage of the green products. The increase in extent of green products' market coverage will directly correspond to the acceptability of the same over non-green products. The factor generates a reliability value of 0.788 .

Factor 4: Green Product \& Brand: This factor signifies that green product $\&$ brand is crucial in creation of credibility of the green products, as they are manufactured in an environment friendly manner which does not harm the eco-system. The non-erroneous performance and exhaustive variety (i.e. range) of green products is essentially significant in generating long-term trust worthiness among the customers over the non-green products. This factor generated herein achieves a reliability value of 0.779 .

Factor 5: Eco-label: This factor proposes that eco-labels are becoming essentially noticeable these days, thus possess higher importance for dissemination of the meaningful product / brand related information to the consumers. The accurateness of information will tend to generate a more conducive brand preference among the consumer as they will be able to relate it positively with their product / brand experience. This factor earns a reliability value of 0.815 . 
ISSN 2349-2317 (Online); DOI: 10.16962/EAPJMRM/issn. 2349-2317/2018; Volume 9 Issue 4 (2018)

\subsubsection{Validation of Green Marketing} Tools' Scale using CFA (Confirmatory Factor Analysis)

Figure - 1 describes the Green Marketing Tools' as a higher order construct (i.e. as a latent variable) with Green Advertising (GA), Green Price (GP), Green Product Availability (GPAv), Green Product \& Brand (GP\&B) and Eco labels (EL) as its dimensions. Confirmatory Factor Analysis (CFA) has been used to evaluate the multidimensionality of Green Marketing Tools'.

Kim \& Mueller (1978) suggested the use of factor scores for imputation of variables in Structural Equation Modelling (SEM). The output of the CFA revealed a good model fit as all the goodness of fit indices were higher than the threshold limits and badness of fit indices were lower than their permissible limits. (Table 7 and Table 8)

\subsection{Investigation of the direct impact of Green Marketing Tools' on Consumers' Green Purchase Intentions}

To ascertain the impact of Green Marketing Tools' on Consumers' Green Purchase Intentions, likewise hypothesis has been formulated which is as follows:
H1: Green Marketing Tools' exhibit a direct significant impact on consumers' Green Purchase Intentions.

The response towards impact of Green Marketing Tools' has been measured on an 18-item / statement construct, measured on a five pointer scale with the responses ranging from 1 to 5 . The reliability of the construct of consumer's Green Purchase Intentions records a reliability value of 0.810 , which is considered appropriate for further analysis.

Figure - 2 details the relationship of the five derived factors of Green Marketing Tools' with Green Purchase Intentions of the consumers' which is being examined. Thus, the relationship between Green Marketing Tools' and consumers' Green Purchase Intentions has been hypothesized.

\subsubsection{Investigation of the relationship} between Green Marketing Tools' and Consumers' Green Purchase Intentions:

To examine the relationship between five derived factors of Green Marketing Tools' and consumers' Green Purchase Intentions, the pair wise correlations is established using the measure of bivaraite correlations. 
ISSN 2349-2317 (Online); DOI: 10.16962/EAPJMRM/issn. 2349-2317/2018; Volume 9 Issue 4 (2018)

All the pair wise correlation scores reveals pertinent values for corresponding significance value which have either $\mathrm{p}<.01$ and $\mathrm{p}<.05$. It is evident from the analysis that all the derived factors of Green Marketing Tools' depicts positive correlations with Green Purchase Intentions which suggests a significant model fit for all the significance value $<.05$. (Table -9$)$

The output of regression analysis reveals unadjusted $\mathrm{R}^{2}$ equivalent to 0.723 while the adjusted $R^{2}$ is equivalent to 0.720 . The adjusted $\mathrm{R}^{2}$ elaborates that the model accounts for 72.0 percent of variation in the dependent variable 'Green Purchase Intentions' which being numerically high signifies significant model fit. (Table - 10)

The analysis of ANOVA achieves the overall significance of the model with Fratio equivalent to 277.610 at significance level of .000 ( $p$ < 0.05). (Table - 11)

The output illustrates the Beta Coefficients with their contribution to the model. The ' $\mathrm{t}$ ' and significance value (p-value) explains the impact of predictor variables (i.e. the deduced five factors of Green Marketing Tools') on the criterion variable (Green Purchase Intentions). The output summary describes that all the predictor variables yield a significant impact on the criterion variable. $($ Table - 12)

Hence, it became apparent that the drafted hypothesis completely gets satisfied i.e. the Green Marketing Tools' demonstrates a direct significant impact on consumers' Green Purchase Intentions. Further, the coefficients in the form of a regression equation are expressed as under:

$\mathrm{Y}($ Green Purchase Intentions $)=0.342+$ 0.622 (Green Advertising) + 0.121 (Green Price) + 0.097 (Green Product Availability) +0.104 (Green Product \& Brand) + 0.141 (Eco labels)

\subsection{Investigation of the direct impact of} Green Marketing Tools' on consumers' Green Buying Behaviour (i.e. Green Purchase Behaviour)

To establish the impact of Green Marketing Tools' on consumers' Green Buying Behaviour (i.e. Green Purchase Behaviour), likewise hypothesis has been formulated which is elaborated as under: 
ISSN 2349-2317 (Online); DOI: 10.16962/EAPJMRM/issn. 2349-2317/2018; Volume 9 Issue 4 (2018)

H2: Green Marketing Tools' exhibit a direct significant impact on the consumers' Green Purchase Behaviour.

The response towards impact of Green Marketing Tools' has been measured on a 18 -item / statement construct, measured on a five pointer scale with the responses ranging from 1 to 5 . The reliability of the construct of consumer's Green Purchase Behaviour achieves a reliability value of 0.856 , which is considered as appropriate for further analysis.

Figure $-\mathbf{3}$ represents the relationship of the five derived factors of Green Marketing Tools' with Green Purchase Behaviour of the consumers' which is being analysed. Thus, the relationship between Green Marketing Tools' and consumers' Green Purchase Behaviour has been hypothesized.

\subsubsection{Investigation of the relationship between Green Marketing Tools' and Consumers' Green Buying Behaviour (i.e.} Green Purchase Behaviour)

To ascertain the relationship between five derived factors of Green Marketing Tools' and consumers' Green Purchase Behaviour, the pair wise correlations is deduced using the measure of bivaraite correlations. All the pair wise correlation scores achieves pertinent values for the corresponding significance level value which encompass either $\mathrm{p}<.01$ or $\mathrm{p}<.05$. Thus, it is apparent from the analysis that all the deduced factors of Green Marketing Tools' results in positive correlations with Green Purchase Behaviour which implies a significant model fit for all the significance value $<.05$ (Table - 13)

The output of regression analysis details unadjusted $\mathrm{R}^{2}$ equivalent to 0.594 while the adjusted $\mathrm{R}^{2}$ comes out to be 0.590 . The adjusted $\mathrm{R}^{2}$ explains that the model accounted for 59.0 percent of variation in the dependent variable 'Green Purchase Behaviour' which being numerically considerable represents a significant model fit. (Table - 14)

The analysis of ANOVA reports the overall significance of the model with F-ratio equivalent to 155.649 at significance level of $.000(\mathrm{p}<0.05) .($ Table - 15)

The output elaborates the Beta Coefficients with their contribution to the model. The ' $t$ ' and significance value ( $\mathrm{p}$-value) identifies the impact of predictor variables (i.e. the 
ISSN 2349-2317 (Online); DOI: 10.16962/EAPJMRM/issn. 2349-2317/2018; Volume 9 Issue 4 (2018)

deduced five factors of Green Marketing Tools') on the criterion variable (Green Purchase Behaviour). The data as defined in related table narrates that all the predictor variables generates a significant impact on the criterion variable. (Table - 16)

Thus, it is conclusive that the hypothesis completely justifies the drafted preposition, that the Green Marketing Tools' depicts a direct significant impact on consumers' Green Purchase Behaviour. Further, the coefficients as written in the form of a regression equation are as under:

$\mathrm{Y}$ (Green Purchase Behaviour) $=1.257+$ 0.455 (Green Advertising) + 0.216 (Green Price $)+0.099$ (Green Product Availability) +0.111 (Green Product \& Brand) + 0.134 (Eco labels)

\subsection{Investigation of the mediation role of} Green Purchase Intentions on the impact of Green Marketing Tools' on consumers' Green Buying Behaviour (i.e. Green Purchase Behaviour)

The established approach of Baron \& Kenny (1986) has been used to determine the mediation role of Green Purchase Intentions on the impact of Green Marketing
Tools' on consumers' Green Purchase Behaviour.

To accomplish this, the following hypothesis has been formulated which is written as under:

H3: Green Purchase Intentions fully mediates the relationship between Green Marketing Tools' and consumers' Green Purchase Behaviour.

Figure - 4 elaborates the relationship of the five derived factors of Green Marketing Tools' with Green Purchase Behaviour with Green Purchase Intentions as a mediator. Thus, the likewise relationship between Green Marketing Tools' and consumers' Green Purchase Behaviour with Green Purchase Intentions as mediator has been hypothesized.

\subsubsection{Investigation of the relationship between Green Marketing Tools' and consumers' Green Buying Behaviour (i.e.} Green Purchase Behaviour) with Green Purchase Intentions as Mediator:

The following steps were performed in sequential manner to ascertain and verify the existence of a mediated relationship between Green Marketing Tools' and consumers' 
ISSN 2349-2317 (Online); DOI: 10.16962/EAPJMRM/issn. 2349-2317/2018; Volume 9 Issue 4 (2018)

Green Purchase Behaviour with Green Purchase Intentions as mediator:

Step 1: The predictor variables should be significantly correlate with the criterion variable. Hence, measure of correlation is used to ascertain the significant correlation of 'Green Marketing Tools' with 'Green Purchase Behaviour'.

Step 2: The predictor variables should significantly correlate with the mediator variable. Hence, measure of correlation is implemented to establish the significant correlation of 'Green Marketing Tools' with 'Green Purchase Intentions'.

Step 3: The mediator variable should significantly correlate with the criterion variable. Hence, measure of correlation is used to recognize the significant correlation of 'Green Purchase Intentions' with 'Green Purchase Behaviour'.

Step 4: The relationship between predictor variables and criterion variable should either become insignificant or reduced when mediator has been controlled. Hence, measure of regression is used to determine the relationship between 'Green Marketing Tools' and 'Green Purchase Behaviour' when 'Green Purchase Intentions' has been controlled.
The output of regression analysis, explains unadjusted $\mathrm{R}^{2}$ equal to 0.419 while the adjusted $R^{2}$ comes out to be 0.416 .

The adjusted $\mathrm{R}^{2}$ reveals that the model represents 41.6 percent of variation in the dependent variable 'Green Purchase Behaviour' which being numerically reasonable suggests a significant model fit. (Table - 17)

The analysis of ANOVA, concludes the overall significance of the model with Fratio equivalent to 383.928 at significance level of $.000(p<0.05)$. (Table - 18)

The results elaborated the Beta Coefficient with its contribution to the model. The ' $t$ ' and significance value ( $\mathrm{p}$-value) reveals the influence of predictor variable (i.e. Green Purchase Intentions) on the criterion variable (Green Purchase Behaviour). The data details that the predictor variable possess a significant influence on the criterion variable. (Table - 19)

Further, the coefficients are expressed in the form of a regression equation as:

Y $($ Green Purchase Behaviour $)=1.060+$ 0.718 (Green Purchase Intentions)

The result of mediation effect of Green Purchase Intentions between the predictors 
ISSN 2349-2317 (Online); DOI: 10.16962/EAPJMRM/issn. 2349-2317/2018; Volume 9 Issue 4 (2018)

(i.e. deduced five factors of Green Marketing Tools') and the criterion variable (i.e. Green Purchase Behaviour (Green Purchase Behaviour), reports their partial correlations described among them in accordance with the steps recommended by Baron and Kenny (1986) as elaborated above. The analysis explains that Green Purchase Intentions is significantly correlated with Green Purchase Behaviour with a correlation value of 0.646 at $p$-value of 0.000 (at $\mathrm{p}<0.05$ ). (Table - 20)

Further, from the analysis as detailed in Table - 20, it is evident that Green Purchase Intentions fully mediates the relationship of the two predictors (i.e. Green Advertising and Green Price) with Green Purchase Behaviour. Further, partially mediates the relationship for the other three predictors (i.e. Green Product Availability, Green Product \& Brand and Eco-labels). Therefore, it is concluded that the drafted hypothesis is satisfied.

\section{CONCLUSION}

The results of this study substantiate that the Green Marketing Tools' exhibits a direct significant impact on consumers' Green Purchase Intentions. This present research finding is also consistent with the outcome achieved by researchers like Chan (2004), Nik Abdul Rashid (2009), Khandelwal \& Bajpai (2011), Ansar, N. (2013) and Mahesh, N. (2013) who studied the similar relationship with one or more green marketing tools' in their research.

Further, this present study also confirms that the Green Marketing Tools' exhibits a direct significant impact on consumers' Green Purchase Behaviour. This current research finding is also consistent with the result obtained by researchers like Gan, C. et. al. (2008), Boztepe, A. (2012), Juwaheer T.D., et. al. (2012) and Mehta, P. (2013) who have studied the alike relationship earlier with one or more green marketing tools' in their research.

Additionally, this present research also concludes that the Green Purchase Intentions fully mediates the relationship of the two predictors (i.e. Green Advertising and Green Price) with Green Purchase Behaviour; and partially mediates the relationship for the other three predictors (i.e. Green Product Availability, Green Product \& Brand and Eco-labels), which was not comprehensively explored the previous research studies. 
ISSN 2349-2317 (Online); DOI: 10.16962/EAPJMRM/issn. 2349-2317/2018; Volume 9 Issue 4 (2018)

\section{MANAGERIAL IMPLICATIONS}

The results of the present study have provided meaningful prerequisite knowledge which the business organizations \& marketers can utilise to understand the consumers' green buying paradox more expansively. The pertinent knowledge of green marketing mix tools' (i.e. green product \& brand, green price, green product availability, green advertising and ecolabels) can be used to develop more comprehensive targeted marketing programs. The mediation analysis will help the business organizations \& marketers to inculcate likewise purchase intentions among consumers for pertinent display of ascertain their lifestyles based buying patterns. Furthermore, the research can also

\section{REFERENCES}

The following is the detailed reference to the research papers, books and doctoral dissertations:

[1] Adkins, S. (2004). Cause Related Marketing: Who Cares Wins. Oxford: Elsevier Butterworth-Heinemann.

[2] Agyeman, C.M. (2014). Consumers' buying behavior towards green green purchase behaviour in their periodic purchases and to enable the consumers' for adoption of a likewise green lifestyle for a better and healthier living.

\section{SCOPE FOR FUTURE RESEARCH}

The present study was undertaken in the state of Punjab (India) which might not have represented all the perceptual ecological prepositions of consumers' present across varied geographical and sociodemographical dimensions. Thus, the future research can encompass cross-cultural or/and cross-national comparisons of consumers' green buying behaviour and to be carried out on sector specific analysis of consumers' green buying behaviour.

products: An exploratory study. International Journal of Management Research and Business Strategy, Vol. 3, 189-197

[3] Ahmad, A. \& Thyagaraj, K. S. (2015). Consumer's intention to purchase green brands: The roles of environmental concern, environmental knowledge and self expressive benefits. Current World Environment, Vol. 10(3), 879-889 
ISSN 2349-2317 (Online); DOI: 10.16962/EAPJMRM/issn. 2349-2317/2018; Volume 9 Issue 4 (2018)

[4] Ali, A. \& Ahmad, I. (2012). Environment Friendly Products: Factors that influence the green purchase intentions of Pakistani Consumers. PJETS, Vol. 2 (1) 84-117

[5] Anderson, J.C., Gerbing, D.W. (1988). Structural Equation Modeling in Practice: A Review \& Recommended two step approach, Psychological Bulletin, Vol. 103 (3)

[6] Ansar, N. (2013). Impact of green marketing on consumer purchase intention. Mediterranean Journal of Social Sciences, Vol. 4 (11), 650-655

[7] Azizan, S.A.M. \& Suki, N.M (2013). Consumers' intention to purchase green product: Insights from Malaysia. World Applied Sciences Journal, Vol. 22(8), 1129-1134.

[8] Bagozzi, P.R. \& Yi., Y. (1988). On the evaluation of Structural Models, Journal of Academy of Marketing Science, Vol. 16 No. 1

[9] Baron, R.M. \& Kenny, D.a. (1986). The moderator-mediator variable distinction in social psychological research: Conceptual, strategic, and statistical considerations. Journal of Personality and Social Psychology, Vol. 51 (6), 1173-82.

[10] Blend, J. R. and van Ravenswaay, E. O. (1999). Measuring Consumer Demand for Ecolabeled Apples. American Journal of Agriculture Economics, Vol. 81 (5), 1072-1077.

[11] Boztepe, A. (2012). Green marketing and its impact on consumer buying behaviour. European Journal of Economic and Political Studies, Vol. $5(1), 5-21$

[12] Browne, M.W. \& Cudeck, R., (1993), Alternative Ways of Assessing Model Fit: In Bollen K. A. and Long J. S. (Eds.). Testing Structural Equation Models. New-bury Park: Sage, 136162.

[13] Chan, Y.K.R. (2004). Consumer responses to environmental advertising in China", Marketing Intelligence \& Planning, Vol. 22 (4), 427-37.

[14] Chyong, H.T., Phang, G, Hasan, H. and Buncha, M.R. (2006). Going green: A study of consumers' willingness to pay for green products 
ISSN 2349-2317 (Online); DOI: 10.16962/EAPJMRM/issn. 2349-2317/2018; Volume 9 Issue 4 (2018)

in Kota Kinabalu. International Journal of Business and Society, Vol. 7 (2), 40-54.

[15] Crane, A. (2000). Facing the backlash, green market and strategic reorientation in the 1990s. Journal of Strategic Marketing, Vol. 8, 277- 296

[16] D' Souza, C., Taghian, M. and Khosla, R. (2007). Examination of environmental beliefs and its impact on the influence of price, quality and demographic characteristics with respect to green purchase intention, Journal of Targeting, Measurement and Analysis for Marketing, Vol. 15 (2), 69-78

[17] D’Souza et. al. (2006). An empirical study on the influence of environmental labels on consumers. Corporate Communication: An International Journal, Vol. 11 (2), 162-73.

[18] D’Souza, C. (2004). Ecolabels programmes: a stakeholder (consumer) perspective Corporate Communication: An International Journal, Vol. 9 (3), 179-88.
[19] Delafrooz, N., Taleghani, M. \& Nouri, B. (2014). Effect of green marketing on consumer purchase behavior. http://www.qscience.com/doi/pdf/10.5 339/connect.2014.5 (Retrieved)

[20] Diglel, A. \& Yazdanifard, R. (2014). Green Marketing: It's influence on buying behavior and attitudes of the purchasers towards eco-friendly products. Global Journal of Management and Business Research, Volume 14 (7), 10-17

[21] Drozdenko, R. et. al. (2011). Pricing of Green Products: Premiums Paid, Consumer Characteristics and Incentives. International Journal of Business, Marketing, and Decision Sciences, Volume 4 (1), 106-16.

[22] D'Souza et al. (2006). Green Products and Corporate Strategy: An Empirical Investigation. Society and Business Review, Vol. 1 (2), 144-157.

[23] Easterling, D. et. al. (1996). The greening of advertising: a twenty-five year look at environmental advertising. Journal of Marketing Theory and Practice, Vol.4 (1), 20-33. 
ISSN 2349-2317 (Online); DOI: 10.16962/EAPJMRM/issn. 2349-2317/2018; Volume 9 Issue 4 (2018)

[24] Ferraz, B. S. et. al. (2017). Green Products: A Cross-Cultural Study Of Attitude, Intention And Purchase Behavior. Mackenzie Management Review, Vol. 18(5), 12-38

[25] Gan, C. et. al. (2008). Consumers' purchasing behavior towards green products in New Zealand, Innovative Marketing, Vol 4 (1), 93-102

[26] Glegg, G., Wee, H.Y., Ozanne, L. \& Kao, T. (2005). Barriers to Green Buying: Household Chemicals. A Report for the Clean Water Initiative. Plymouth: Marine and Coastal Policy Research Group, University of Plymouth.

[27] Habib, A., Idrees, A. and Kursheed, A. (2010). Factors in environmental advertising influencing consumer's purchase intention. European Journal of Scientific Research, Vol. 48 (2), 217-26.

[28] Hair, J. F., Anderson, R. E., Tatham, R. L. and Black, W. C. (2010). Multivariate Data Analysis. (7th Edition). Englewood Cliffs, NJ: Prentice-Hall.
[29] Hartmann, P. \& Ibáñez, V.A. (2006). Green value added. Marketing Intelligence \& Planning, Vol. 24, 67380

[30] Hawkins, D.I. et. al. (1998). Consumer Behaviour: Building Market Strategy, McGraw-Hill, Boston, MA.

[31] Hindol, R. (2012). Environmental Advertising and its Effects on Consumer Purchasing Patterns in West Bengal, India. Research Journal of Management Sciences, Vol. 1(4), 1620.

[32] Hu, L. T., \& Bentler, P. M. (1999). Cutoff criteria for fit indexes in covariance structure analysis: Conventional criteria versus new alternatives. Structural equation modeling: A Multidisciplinary Journal, 6(1), 1-55.

[33] Ishaswini \& Datta, S.K. (2011). Proenvironmental concern influencing green buying: A study on Indian consumers. International Journal of Business and Management, Vol. 6 (6), 124-133. 
ISSN 2349-2317 (Online); DOI: 10.16962/EAPJMRM/issn. 2349-2317/2018; Volume 9 Issue 4 (2018)

[34] Jain, S.K. \& Kaur, G. (2006). Role of socio-demographics in segmenting and profiling green consumers. Journal of International Consumer Marketing, Vol. 18(3), 107-146.

[35] Juwaheer T.D., Pudaruth, S. \& Noyaux, M.M.E. (2012). Analyzing the impact of green marketing strategies on consumer purchase patterns in Mauritius. World Journal of Entrepreneurship, Management and Sustainable Development, Vol. 8 (1), 36-59

[36] Kassaye, W.W. (2001). Green dilemma. Marketing Intelligence \& Planning, Vol. 19 (6), 444-55.

[37] Khandelwal, U. \& Bajpai, N. (2011). A Study on Green Advertisement and its Impact on Consumer Purchase Intention. Journal of Creative Communications, Vol. 6 (3), 259-276

[38] Kim, J. O., \& Mueller, C. W. (1978). Factor analysis: Statistical methods and practical issues. Sage, Vol. 14.

[39] Laroche M. et. al. (2001). Targeting consumers who are willing to pay more for environmentally friendly products. Journal of Consumer Marketing, Vol. 18 (6), 503-520.

[40] Leire, C. and Thidell, A. (2005). Product-related environmental information to guide consumer purchases e a review and analysis of research on perceptions, understanding and use among Nordic consumers. Journal of Cleaner Production, Vol. 13 (10), 61-70.

[41] Mahapatra, S. (2013). A study on consumer's perception for green products: An empirical study from India. International Journal of Management \& Information Technology, Vol. 7 (1), 924-933.

[42] Mahesh, N. (2013). Consumer's perceived value, attitude and purchase intention of green products. SMS Varanasi, Vol. IX (1), 36-43

[43] Mainieri, T. et. al. (1997). Green buying: The influence of environmental concern on consumer behavior. Journal of Social Psychology, Vol. 137, 189-204. 


\section{ELK ASIA PACIFIC JOURNAL OF MARKETING \& RETAIL MANAGEMENT}

ISSN 2349-2317 (Online); DOI: 10.16962/EAPJMRM/issn. 2349-2317/2018; Volume 9 Issue 4 (2018)

[44] Malhotra, N.K. \& Dash, S. (2010). Marketing Research. $5^{\text {th }}$ Edition. New Delhi: Pearson Education.

[45] Mamun, A. A., Mohiuddin, M., Ahmad, G.B., Thurasamy, R. \& Fazal, S.A. (2018). Recycling Intention and Behavior among Low-Income Households, Sustainability, Vol. 10; doi:10.3390/su10072407

[46] Mathur, L.K. and Mathur, I. (2000). An analysis of the wealth effects of green market strategies. Journal of Business Research, Vol. 50 (1), 193200.

[47] Mehta, P. (2013). Consumer behaviour towards green products in urban Punjab (Doctoral Dissertation). Guru Nanak Dev University, Amritsar, India.

[48] Menon, A., \& Menon, A. (1997). Enviropreneurial Marketing Strategy: The Emergence of Corporate Environmentalism as Market Strategy. Journal of Marketing, Vol. 61, 51-67.

[49] Mishra, P. \& Sharma, P. (2010). Green Marketing in India: Emerging opportunities and challenges. Journal of Engineering, Science \& Management Education, Vol. 3, 9-14

[50] Ng, S., and Paladino, A. (2009). Examining the influences of intention to purchase green mobile phones among young consumers: An Empirical Analysis. ANZMAC, 1-8.

[51] Nik Abdul Rashid, N.R. (2009). Awareness of eco-label in Malaysia's green marketing initiative. International Journal of Business and Management, Vol. 4 (8), 132-41.

[52] Pfanner, E 2008. Cooling off on dubious eco-friendly claims', The New York Times, 18 July, 3.

[53] Polonsky, M.J., Calson, L., Grove, S., \& Kangun, N. (1997). International environmental marketing claims: real changes or simple posturing? International Marketing Review, Vol.14 (4), 218-32.

[54] Polonsky, M., \& Kilbourne, W.E. (2005). Environmental attitudes and their relation to the dominant social paradigm among university students in New Zealand and Australia. 
ISSN 2349-2317 (Online); DOI: 10.16962/EAPJMRM/issn. 2349-2317/2018; Volume 9 Issue 4 (2018)

Australasian Marketing Journal, Vol. 13 (2), 37-48.

[55] Pujari, D., \& Wright, G. (1996). Developing environmentallyconscious product strategy: A qualitative study of selected companies in Britain and Germany. Marketing Intelligence and Planning, Vol. 14 (1), 19-28.

[56] Rahbar, E. \& Wahid, N.A. (2011). Investigation of green marketing tools' on consumers' purchase behaviour. Business Strategy Series, Vol. 12 (2), 73-83

[57] Ramayah, T., Lee, J. WC., and Mohamad, O. (2010). Green Product Purchase Intention: Some Insights from a Developing Country. Resources, Conservation and Recycling, Vol. 54, 1419-1427.

[58] Rex, E. \& Baumann, H. (2007). Beyond ecolabels: what green marketing can learn from conventional marketing. Journal of Cleaner Production, Vol. 15, 567-76.

[59] Sammer, K. \& Wüstenhagen, R. (2006). The influence of eco-labelling on consumer behaviour - results of a discrete choice analysis for washing machines. Business Strategy and the Environment, Vol. 15 (3), 185-99.

[60] Saxena, R. \& Khandelwal, P. K. (2010). Can Green Marketing be used as a tool for Sustainable Growth? : A study performed on consumers in India - A Emerging Economy. International Journal of Environmental, Cultural, Economic and Social Sustainability, Vol. 6 (2), 277-291

[61] Schiffman, L.G. \& Kanuk, L.L. $\left(9^{\text {th }}\right.$ Edition) (2008). Consumer Behaviour. New Delhi, Prentice -Hall of India Pvt. Ltd., G-9.

[62] Stanton, W.J. and Futrell, C. (1987). Fundamentals of Marketing, New York, NY: McGraw-Hill.

[63] Suki, N.M. (2013). Green awareness effects on consumers' purchasing decision: Some insights from Malaysia. IJAPS, Vol. 9 (2), 49-63

[64] Thorgersen, J. (2002). Promoting green consumer behaviour with ecolabels: New Tools for Environmental 
ISSN 2349-2317 (Online); DOI: 10.16962/EAPJMRM/issn. 2349-2317/2018; Volume 9 Issue 4 (2018)

Protection: Education, Information and Voluntary Measures, Washington, DC: National Academy Press.

[65] Veluri, K.K. (2012). Green Marketing: Indian consumer awareness and marketing influence on buying decision. International Journal of Research in Commerce and Management, Vol. 3 (2), 60-64

[66] Vermeir, I. \& Verbeke, W. (2004). Sustainable food consumption: Exploring the consumer attitudebehaviour gap, Working Paper, October (04/268), 24.

[67] Whitson, D. and Henry, W. (1996). What's in a Label? Environmental Issues in Product Packaging, New York, NY: The Haworth Press, 29-43.

[68] Zhu, B. (2013). The impact of green advertising on consumer purchase intention of green products. World Review of Business Research, Vol. 3 (3), 72-80
[69] Zinkhan, G.M. \& Calson, L. (1995). Green advertising and the reluctant consumer', Journal of Advertising, Vol. 24 (2), 1-6.

The following is the detailed reference to the web resources:

[70] http://timesofindia.indiatimes.com/bus iness/india-business/Indianconsumers-willing-to-pay-moreforeco-friendlyproducts/articleshow/26904903.cms, as accessed \& retrieved on 10th January' 2014

[71] http://www.devinfo.org/indiacensuspo pulationtotals2011/libraries/aspx/Hom e.aspx?refer_url=catalog\&jsonAreasT opics $=\{\% 22 \mathrm{apn} \% 22: \% 2255 \% 22, \% 22 \mathrm{i}$ $\% 22: \% 22$ Literacyrate, $7+y r s \% 22, \% 22 \mathrm{i}$ _n\%22:\%2215\%22,\%22a\%22:\%22Ind i a\% 22,\%22a_n\%22:\%2218274\%22\} as accessed \& retrieved on 20th January' 2014 
ISSN 2349-2317 (Online); DOI: 10.16962/EAPJMRM/issn. 2349-2317/2018; Volume 9 Issue 4 (2018)

\section{LIST OF FIGURES}

Figure - 1: Construct for validation of Green Marketing Tools' scale using CFA

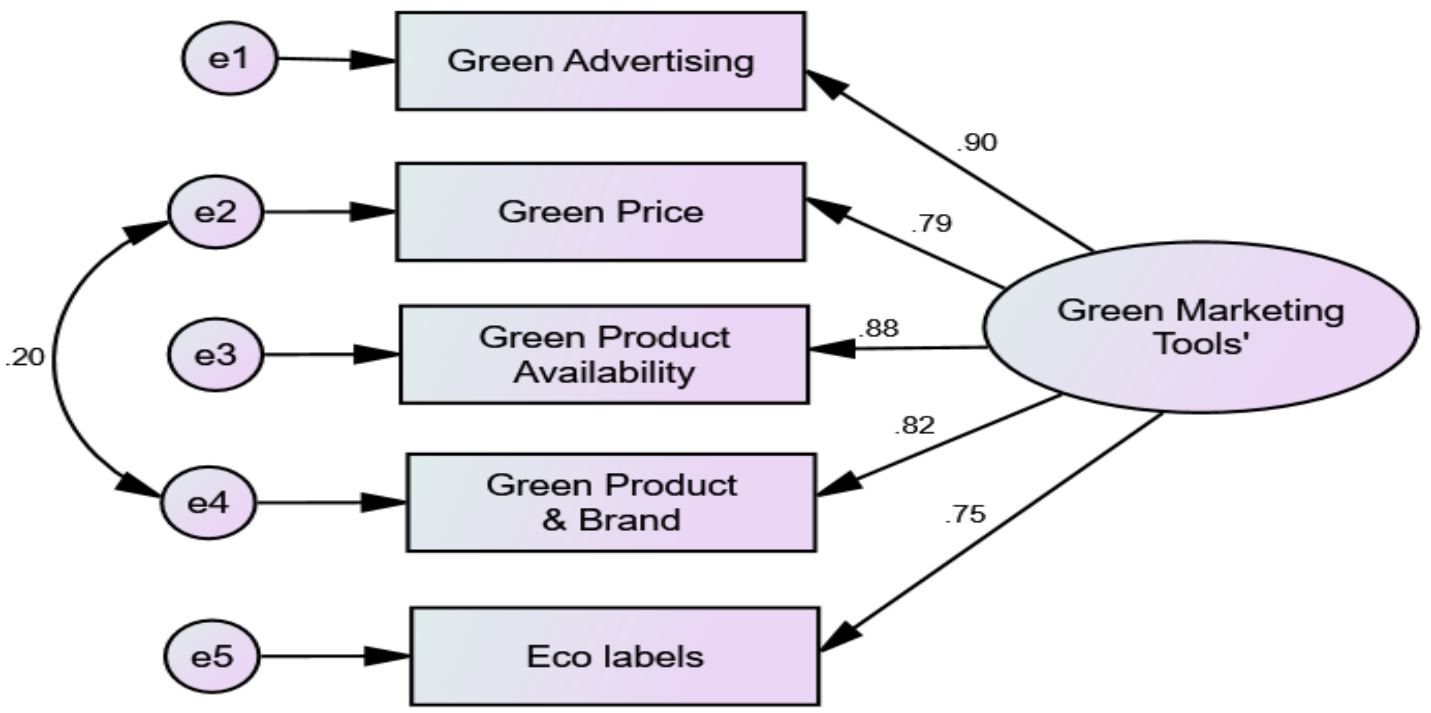

Source: Prepared by Author

Figure - 2: Hypothesizing the relationship between Green Marketing Tools' and Green Purchase Intentions

Green Marketing Tools'

Green Purchase Intentions

Source: Prepared by Author

Figure - 3: Hypothesizing the relationship between Green Marketing Tools' and Green Purchase Behaviour
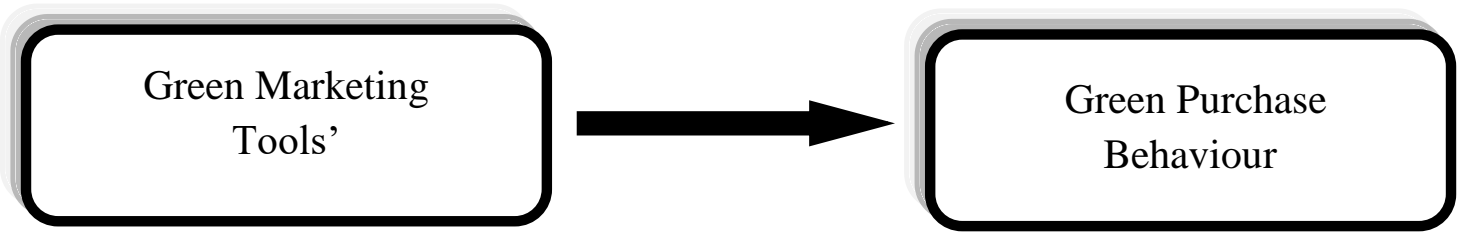

Source: Prepared by Author 
ISSN 2349-2317 (Online); DOI: 10.16962/EAPJMRM/issn. 2349-2317/2018; Volume 9 Issue 4 (2018)

Figure - 4: Hypothesizing the relationship between Green Marketing Tools' and Green Purchase Behaviour with Green Purchase Intentions as Mediator

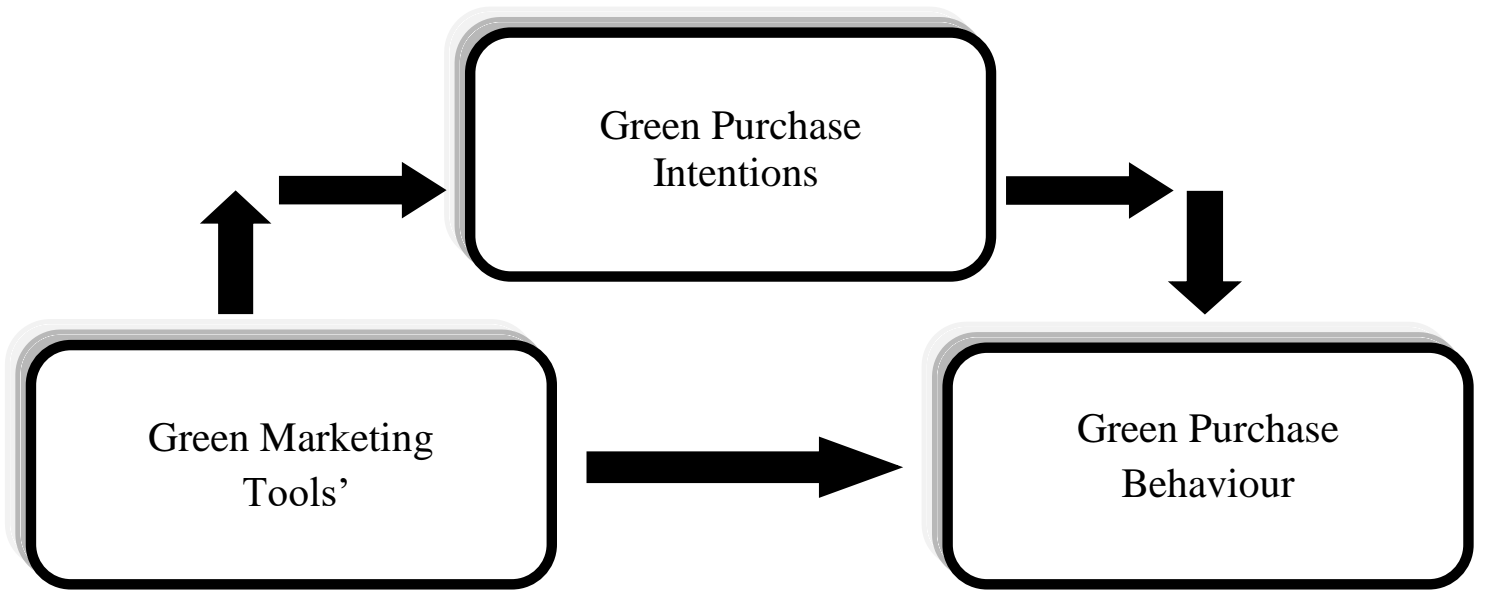

Source: Prepared by Author

\section{LIST OF TABLES}

List Table - 1: Published review sources referred for questionnaire scale construction

\begin{tabular}{|c|c|l|}
\hline Scale Construct & Number of Statements & Source (Author and Year) \\
\hline & & Jain \& Kaur (2006) \\
& D'souza et. al. (2007) \\
Rahbar \& Wahid (2011) & Juwaheer et. al. (2012) \\
Green Marketing & Hindol, R. (2012) \\
Tools' & (Eighteen) & $\begin{array}{l}\text { Azizan \& Suki (2013) } \\
\text { Mahapatra, S. (2013) } \\
\end{array}$ \\
& & Mehta, P. (2013) \\
& & Suki, N.M. (2013) \\
& & Delafrooz, N. et. al. (2014) \\
\hline
\end{tabular}

Source: Prepared by Author 
ISSN 2349-2317 (Online); DOI: 10.16962/EAPJMRM/issn. 2349-2317/2018; Volume 9 Issue 4 (2018)

Table - 2: KMO and Bartlett's Test (for construct of green marketing tools')

\begin{tabular}{|c|c|c|}
\hline \multicolumn{2}{|c|}{ Kaiser-Meyer-Olkin Measure of Sampling Adequacy. } & 0.794 \\
\hline \multirow{3}{*}{ Bartlett's Test of Sphericity } & Approx. Chi-Square & 823.519 \\
\cline { 2 - 3 } & df & 153 \\
\cline { 2 - 3 } & Sig. & .000 \\
\hline
\end{tabular}

Source: Prepared by Author

Table - 3: Communalities and Initial Eigen Values of Variables (for construct of green marketing tools')

\begin{tabular}{|c|c|c|c|c|c|c|}
\hline \multicolumn{3}{|c|}{ Communalities } & \multirow{2}{*}{ Component } & \multicolumn{3}{c|}{ Initial Eigenvalues } \\
\cline { 5 - 7 } & Initial & Extraction & & Total & \% of Variance & Cumulative \% \\
\hline GMT1 & 1.000 & .738 & $\mathbf{1}$ & $\mathbf{4 . 5 7 1}$ & $\mathbf{2 5 . 3 9 4}$ & $\mathbf{2 5 . 3 9 4}$ \\
\hline GMT2 & 1.000 & .802 & $\mathbf{2}$ & $\mathbf{2 . 8 9 8}$ & $\mathbf{1 6 . 1 0 0}$ & $\mathbf{4 1 . 4 9 4}$ \\
\hline GMT3 & 1.000 & .862 & $\mathbf{3}$ & $\mathbf{1 . 5 8 2}$ & $\mathbf{8 . 7 8 9}$ & $\mathbf{5 0 . 2 8 3}$ \\
\hline GMT4 & 1.000 & .826 & $\mathbf{4}$ & $\mathbf{1 . 3 5 8}$ & $\mathbf{7 . 5 4 4}$ & $\mathbf{5 7 . 8 2 8}$ \\
\hline GMT5 & 1.000 & .589 & $\mathbf{5}$ & $\mathbf{1 . 1 9 4}$ & $\mathbf{6 . 6 3 3}$ & $\mathbf{6 4 . 4 6 1}$ \\
\hline GMT6 & 1.000 & .804 & 6 & .981 & 5.450 & 69.911 \\
\hline GMT7 & 1.000 & .507 & 7 & .885 & 4.917 & 74.828 \\
\hline GMT8 & 1.000 & .750 & 8 & .816 & 4.533 & 79.361 \\
\hline GMT9 & 1.000 & .651 & 9 & .701 & 3.894 & 83.256 \\
\hline GMT10 & 1.000 & .653 & 10 & .604 & 3.356 & 86.611 \\
\hline GMT11 & 1.000 & .562 & 11 & .484 & 2.689 & 89.3 \\
\hline GMT12 & 1.000 & .740 & 12 & .460 & 2.556 & 91.856 \\
\hline GMT13 & 1.000 & .732 & 13 & .352 & 1.956 & 93.811 \\
\hline GMT14 & 1.000 & .557 & 14 & .318 & 1.767 & 95.578 \\
\hline GMT15 & 1.000 & .737 & 15 & .262 & 1.456 & 97.033 \\
\hline GMT16 & 1.000 & .756 & 16 & .222 & 1.233 & 98.267 \\
\hline GMT17 & 1.000 & .695 & 17 & .169 & 0.939 & 99.206 \\
\hline
\end{tabular}


ISSN 2349-2317 (Online); DOI: 10.16962/EAPJMRM/issn. 2349-2317/2018; Volume 9 Issue 4 (2018)

\begin{tabular}{|c|c|c|c|c|c|c|}
\hline GMT18 & 1.000 & .623 & 18 & .143 & 0.794 & 100 \\
\hline \\
Extraction Method: Principal Component Analysis. \\
\hline
\end{tabular}

Source: Prepared by Author

Table - 4: Total Variance Explained (for construct of green marketing tools')

\begin{tabular}{|c|c|c|c|c|c|c|}
\hline \multicolumn{7}{|c|}{ Total Variance Explained } \\
\hline \multirow{2}{*}{ Component } & \multicolumn{3}{|c|}{ Initial Eigenvalues } & \multicolumn{3}{|c|}{$\begin{array}{c}\text { Rotation Sums of Squared } \\
\text { Loadings }\end{array}$} \\
\cline { 2 - 7 } & Total & $\begin{array}{c}\text { \% of } \\
\text { Varianc } \\
\text { e }\end{array}$ & $\begin{array}{c}\text { Cumulativ } \\
\text { e \% }\end{array}$ & Total & $\begin{array}{c}\text { \% of } \\
\text { Varianc } \\
\text { e }\end{array}$ & $\begin{array}{c}\text { Cumulativ } \\
\text { e \% }\end{array}$ \\
\hline $\mathbf{1}$ & $\mathbf{4 . 5 7 1}$ & $\mathbf{2 5 . 3 9 4}$ & $\mathbf{2 5 . 3 9 4}$ & $\mathbf{3 . 7 1 7}$ & $\mathbf{2 0 . 6 5 0}$ & $\mathbf{2 0 . 6 5 0}$ \\
\hline $\mathbf{2}$ & $\mathbf{2 . 8 9 8}$ & $\mathbf{1 6 . 1 0 0}$ & $\mathbf{4 1 . 4 9 4}$ & $\mathbf{2 . 3 7 9}$ & $\mathbf{1 3 . 2 1 7}$ & $\mathbf{3 3 . 8 6 7}$ \\
\hline $\mathbf{3}$ & $\mathbf{1 . 5 8 2}$ & $\mathbf{8 . 7 8 9}$ & $\mathbf{5 0 . 2 8 3}$ & $\mathbf{1 . 9 9 7}$ & $\mathbf{1 1 . 0 9 4}$ & $\mathbf{4 4 . 9 6 1}$ \\
\hline $\mathbf{4}$ & $\mathbf{1 . 3 5 8}$ & $\mathbf{7 . 5 4 4}$ & $\mathbf{5 7 . 8 2 8}$ & $\mathbf{1 . 8 2 4}$ & $\mathbf{1 0 . 1 3 3}$ & $\mathbf{5 5 . 0 9 4}$ \\
\hline $\mathbf{5}$ & $\mathbf{1 . 1 9 4}$ & $\mathbf{6 . 6 3 3}$ & $\mathbf{6 4 . 4 6 1}$ & $\mathbf{1 . 6 8 6}$ & $\mathbf{9 . 3 6 7}$ & $\mathbf{6 4 . 4 6 1}$ \\
\hline 6 & .981 & 5.450 & 69.911 & & & \\
\hline 7 & .885 & 4.917 & 74.828 & & & \\
\hline
\end{tabular}

\begin{tabular}{|c|c|c|c|}
\hline 8 & .816 & 4.533 & 79.361 \\
\hline 9 & .701 & 3.894 & 83.256 \\
\hline 10 & .604 & 3.356 & 86.611 \\
\hline 11 & .484 & 2.689 & 89.3 \\
\hline 12 & .460 & 2.556 & 91.856 \\
\hline 13 & .352 & 1.956 & 93.811 \\
\hline 14 & .318 & 1.767 & 95.578 \\
\hline 15 & .262 & 1.456 & 97.033 \\
\hline 16 & .222 & 1.233 & 98.267 \\
\hline 17 & .169 & 0.939 & 99.206 \\
\hline
\end{tabular}


ISSN 2349-2317 (Online); DOI: 10.16962/EAPJMRM/issn. 2349-2317/2018; Volume 9 Issue 4 (2018)

\begin{tabular}{|c|c|c|c|l|}
\hline 18 & .143 & 0.794 & 100 & \\
\hline Extraction Method: Principal Component Analysis. \\
\hline
\end{tabular}

Source: Prepared by Author

Table - 5: Rotated Component Matrix ${ }^{a}$ (for construct of green marketing tools')

\begin{tabular}{|c|c|c|c|c|c|}
\hline \multirow{2}{*}{$\begin{array}{c}\text { Statement } \\
\text { Label }\end{array}$} & \multicolumn{5}{|c|}{ Component } \\
\hline GMT4 & .885 & & & $\mathbf{3}$ & $\mathbf{5}$ \\
\hline GMT17 & .781 & & & & \\
\hline GMT18 & .720 & & & & \\
\hline GMT5 & .623 & & & & \\
\hline GMT7 & .515 & & & & \\
\hline GMT16 & & .801 & & & \\
\hline GMT14 & & .769 & & & \\
\hline GMT15 & & .603 & & & \\
\hline GMT9 & & & .794 & & \\
\hline GMT10 & & & .695 & & \\
\hline GMT8 & & & .574 & & \\
\hline GMT1 & & & & .873 & \\
\hline GMT2 & & & & .857 & \\
\hline GMT3 & & & & .619 & \\
\hline GMT13 & & & & .550 & \\
\hline GMT6 & & & & .523 & \\
\hline GMT11 & & & & & .875 \\
\hline GMT12 & & & & & \\
\hline Extraction Method: Principal Component Analysis. \\
Rotation Method: Varimax with Kaiser Normalization. & \\
\hline a. Rotation converged in 9 iterations. & & & \\
\hline
\end{tabular}

Source: Prepared by Author 
Table - 6: Naming of the factors (for construct of green marketing tools')

\begin{tabular}{|c|c|c|c|c|}
\hline $\begin{array}{c}\text { Factor } \\
\text { (Variance } \\
\text { Explained) }\end{array}$ & $\begin{array}{c}\text { Statement } \\
\text { Label }\end{array}$ & Statements & $\begin{array}{c}\text { Factor } \\
\text { Loadings }\end{array}$ & $\begin{array}{c}\text { Reliability } \\
\text { of the } \\
\text { factor }\end{array}$ \\
\hline \multirow{5}{*}{$\begin{array}{l}\text { Factor 1: } \\
\text { Green } \\
\text { Advertising } \\
(20.650 \%)\end{array}$} & GMT4 & $\begin{array}{l}\text { Green advertisements are designed } \\
\text { to educate the customers regarding } \\
\text { the benefits of green products. }\end{array}$ & .885 & \multirow{7}{*}{0.831} \\
\hline & GMT17 & $\begin{array}{l}\text { Informational campaigns are } \\
\text { essential to promote green products } \\
\text { appropriately. }\end{array}$ & .781 & \\
\hline & GMT18 & $\begin{array}{l}\text { Green advertising does increase } \\
\text { my knowledge and understanding } \\
\text { towards green products. }\end{array}$ & .720 & \\
\hline & GMT5 & $\begin{array}{l}\text { Advertised information of } \\
\text { packaging is important for the } \\
\text { customer for making an informed } \\
\text { green purchased decision. }\end{array}$ & .623 & \\
\hline & GMT7 & $\begin{array}{l}\text { Green advertisements have } \\
\text { overstated product expectations } \\
\text { and do not meet the customers } \\
\text { purchase requirements. }\end{array}$ & .515 & \\
\hline \multirow{2}{*}{ Factor 2: } & GMT16 & $\begin{array}{l}\text { Paying premium price for green } \\
\text { products is acceptable because of } \\
\text { their benefits. }\end{array}$ & .801 & \\
\hline & GMT14 & Companies use green price to earn & .769 & \\
\hline
\end{tabular}


ISSN 2349-2317 (Online); DOI: 10.16962/EAPJMRM/issn. 2349-2317/2018; Volume 9 Issue 4 (2018)

\begin{tabular}{|c|c|c|c|c|}
\hline \multirow[t]{2}{*}{$\begin{array}{l}\text { Green Price } \\
(13.217 \%)\end{array}$} & & $\begin{array}{l}\text { premium price for their green } \\
\text { products. }\end{array}$ & & \multirow[t]{2}{*}{0.795} \\
\hline & GMT15 & $\begin{array}{l}\text { Green products generally possess a } \\
\text { sizeable upward variation in price } \\
\text { as compare to non-green products. }\end{array}$ & .603 & \\
\hline \multirow{3}{*}{$\begin{array}{c}\text { Factor 3: } \\
\text { Green Product } \\
\text { Availability } \\
(11.094 \%)\end{array}$} & GMT9 & $\begin{array}{l}\text { Green products are widely } \\
\text { available in the marketplace like } \\
\text { non-green products. }\end{array}$ & .794 & \multirow{3}{*}{0.788} \\
\hline & GMT10 & $\begin{array}{l}\text { Availability of green products is } \\
\text { comprehensive in the market. }\end{array}$ & .695 & \\
\hline & GMT8 & $\begin{array}{l}\text { Green products are available in } \\
\text { only selected retail shops / stores. }\end{array}$ & .574 & \\
\hline \multirow{5}{*}{$\begin{array}{c}\text { Factor 4: } \\
\text { Green } \\
\text { Product } \\
\text { \& Brand } \\
(10.133 \%)\end{array}$} & GMT1 & $\begin{array}{l}\text { Green products contain natural } \\
\text { ingredients which do not pollute } \\
\text { the environment. }\end{array}$ & .873 & \multirow{5}{*}{0.779} \\
\hline & GMT2 & $\begin{array}{l}\text { Green brand is a symbol of } \\
\text { credibility and trustworthiness. }\end{array}$ & .857 & \\
\hline & GMT3 & $\begin{array}{l}\text { Green products matches with my } \\
\text { life style and buying habits. }\end{array}$ & .619 & \\
\hline & GMT13 & $\begin{array}{l}\text { I feel green products are lower in } \\
\text { performance as compared to non- } \\
\text { green products. }\end{array}$ & .550 & \\
\hline & GMT6 & $\begin{array}{l}\text { Variety (i.e. range) of green } \\
\text { products is high in the market } \\
\text { place as compared to non-green }\end{array}$ & .523 & \\
\hline
\end{tabular}


ISSN 2349-2317 (Online); DOI: 10.16962/EAPJMRM/issn. 2349-2317/2018; Volume 9 Issue 4 (2018)

\begin{tabular}{|c|c|c|c|c|}
\hline & & products. & & \\
\hline \multirow{2}{*}{$\begin{array}{l}\text { Factor 5: Eco } \\
\text { Labels } \\
(9.367 \%)\end{array}$} & GMT11 & $\begin{array}{l}\text { Eco-labels on green products } \\
\text { possess high visibility and are } \\
\text { easily communicable. }\end{array}$ & .875 & \multirow[t]{2}{*}{0.815} \\
\hline & GMT12 & $\begin{array}{l}\text { I find information in green labels } \\
\text { to be accurate and correct. }\end{array}$ & .721 & \\
\hline
\end{tabular}

Source: Prepared by Author

Table - 7: Model Fit Indices of Green Marketing Tools' Scale

\begin{tabular}{|c|l|c|}
\hline \multicolumn{1}{|c|}{ Index Particular } & \multicolumn{1}{|c|}{ Recommended Values } & Derived Values \\
\hline Chi Square / Degree of freedom & $\leq 3$, Bagozzi \& Yi (1988) & 0.735 \\
\hline GFI & $\geq 0.85, \mathrm{Hu} \&$ Bentler (1999) & 0.972 \\
\hline AGFI & $\geq 0.80$, Hu \& Bentler (1999) & 0.941 \\
\hline NFI & $\geq 0.90$, Anderson \& Gerbing (1988) & 0.954 \\
\hline IFI & $\geq 0.90$, Anderson \& Gerbing (1988) & 0.963 \\
\hline CFI & $\geq 0.90$, Anderson \& Gerbing (1988) & 0.964 \\
\hline RMR & $\leq 0.08$, Browne and Cudeck (1993) & 0.014 \\
\hline RMSEA & $\leq 0.05$, Browne and Cudeck (1993) & 0.009 \\
\hline
\end{tabular}

Source: Prepared by Author

Table - 8: Psychometric properties of Green Marketing Tools' Scale 
ISSN 2349-2317 (Online); DOI: 10.16962/EAPJMRM/issn. 2349-2317/2018; Volume 9 Issue 4 (2018)

\begin{tabular}{|c|l|c|c|c|c|}
\hline \multirow{2}{*}{ S.No. } & \multicolumn{2}{|c|}{ Factor based dimension } & \multirow{2}{*}{$\begin{array}{c}\text { Std. Factor } \\
\text { Loadings }\end{array}$} & AVE & \multirow{2}{*}{ CR } \\
\cline { 2 - 4 } & \multicolumn{1}{|c|}{ Description } & Abbrv. & & & \\
\hline 1 & Green Advertising & GA & 0.896 & & \\
\hline 2 & Green Price & GP & 0.787 & & \multirow{2}{*}{0.803} \\
\hline 3 & Green Product Availability & GPAv & 0.877 & \multirow{2}{*}{0.915} \\
\hline 4 & Green Product \& Brand & GP\&B & 0.816 & & \\
\hline 5 & Eco labels & EL & 0.749 & & \\
\hline
\end{tabular}

Source: Prepared by Author

Table - 9: Pair-wise (bivaraite) correlations of derived factors of Green Marketing Tools' with Green Purchase Intentions

\begin{tabular}{|c|c|c|c|c|c|c|c|}
\hline \multicolumn{2}{|c|}{$\begin{array}{l}\text { Pair-wise correlations } \\
\downarrow\end{array}$} & \multirow{2}{*}{$\begin{array}{c}\text { Green } \\
\text { Advertising } \\
\mathbf{1}\end{array}$} & \multirow[t]{2}{*}{$\begin{array}{l}\text { Green } \\
\text { Price }\end{array}$} & \multirow[t]{2}{*}{$\begin{array}{c}\text { Green } \\
\text { Product } \\
\text { Availability }\end{array}$} & \multirow[t]{2}{*}{$\begin{array}{l}\text { Green } \\
\text { Product } \\
\text { \& Brand }\end{array}$} & \multirow[t]{2}{*}{$\begin{array}{l}\text { Eco- } \\
\text { labels }\end{array}$} & \multirow[t]{2}{*}{$\begin{array}{c}\text { Green } \\
\text { Purchase } \\
\text { Intentions }\end{array}$} \\
\hline \multirow{2}{*}{$\begin{array}{c}\text { Green } \\
\text { Advertising }\end{array}$} & $\begin{array}{c}\text { Pearson } \\
\text { Correlation }\end{array}$ & & & & & & \\
\hline & $\begin{array}{c}\text { Sig. } \\
\text { (2-tailed) }\end{array}$ & & & & & & \\
\hline \multirow{2}{*}{ Green Price } & $\begin{array}{c}\text { Pearson } \\
\text { Correlation }\end{array}$ & $.384^{* *}$ & 1 & & & & \\
\hline & $\begin{array}{c}\text { Sig. } \\
\text { (2-tailed) }\end{array}$ & .000 & & & & & \\
\hline \multirow{2}{*}{$\begin{array}{c}\text { Green } \\
\text { Product } \\
\text { Availability }\end{array}$} & $\begin{array}{c}\text { Pearson } \\
\text { Correlation }\end{array}$ & $.621^{* *}$ & $.206^{* *}$ & 1 & & & \\
\hline & $\begin{array}{c}\text { Sig. } \\
\text { (2-tailed) }\end{array}$ & .000 & .009 & & & & \\
\hline
\end{tabular}


ISSN 2349-2317 (Online); DOI: 10.16962/EAPJMRM/issn. 2349-2317/2018; Volume 9 Issue 4 (2018)

\begin{tabular}{|c|c|c|c|c|c|c|c|}
\hline \multirow{2}{*}{$\begin{array}{c}\text { Green } \\
\text { Product \& } \\
\text { Brand }\end{array}$} & $\begin{array}{c}\text { Pearson } \\
\text { Correlation }\end{array}$ & $.328^{* *}$ & $.193^{* *}$ & $.243^{* *}$ & 1 & & \\
\hline & $\begin{array}{c}\text { Sig. } \\
\text { (2-tailed) }\end{array}$ & .000 & .000 & .003 & & & \\
\hline \multirow{2}{*}{ Eco-labels } & $\begin{array}{c}\text { Pearson } \\
\text { Correlation }\end{array}$ & $.651^{* *}$ & $.186^{*}$ & $.630^{* * *}$ & $.358^{* *}$ & 1 & \\
\hline & $\begin{array}{c}\text { Sig. } \\
\text { (2-tailed) }\end{array}$ & .000 & .012 & .000 & .000 & & \\
\hline \multirow{2}{*}{$\begin{array}{c}\text { Green } \\
\text { Purchase } \\
\text { Intentions }\end{array}$} & $\begin{array}{c}\text { Pearson } \\
\text { Correlation }\end{array}$ & $.486^{* *}$ & $.368^{* *}$ & $.539^{* *}$ & $.249^{* *}$ & $.404^{* *}$ & 1 \\
\hline & $\begin{array}{c}\text { Sig. } \\
\text { (2-tailed) }\end{array}$ & .000 & .000 & .000. & .002 & .000 & \\
\hline
\end{tabular}

Source: Prepared by Author

Table - 10: Model Summary ${ }^{\mathrm{b}}$ (Enter Method) for regression analysis between Green Marketing Tools' and Green Purchase Intentions:

\begin{tabular}{|c|c|c|c|c|c|c|c|c|c|}
\hline Model & $\mathbf{R}$ & $\mathbf{R}$ & Adjusted & Std. Error & \multicolumn{5}{|c|}{ Change Statistics } \\
\cline { 5 - 10 } & & Square & R Square & $\begin{array}{c}\text { of the } \\
\text { Estimate }\end{array}$ & $\begin{array}{c}\text { R Square } \\
\text { Change }\end{array}$ & $\begin{array}{c}\text { F } \\
\text { Change }\end{array}$ & df1 & df2 & $\begin{array}{c}\text { Sig. F } \\
\text { Change }\end{array}$ \\
\hline 1 & $.850^{\mathrm{a}}$ & .723 & .720 & .28201 & .723 & 277.610 & 5 & 532 & .000 \\
\hline
\end{tabular}

a. Predictors: (Constant), Green Advertising, Green Price, Green Product Availability, Green Product \& Brand and Eco-labels

b. Dependent Variable: Green Purchase Intentions

Source: Prepared by Author 
ISSN 2349-2317 (Online); DOI: 10.16962/EAPJMRM/issn. 2349-2317/2018; Volume 9 Issue 4 (2018)

Table - 11: ANOVA $^{\text {a }}$ (Enter Method) for regression analysis between Green Marketing Tools' and Green Purchase Intentions:

\begin{tabular}{|c|l|c|c|c|c|c|}
\hline \multicolumn{2}{|c|}{ Model } & $\begin{array}{c}\text { Sum of } \\
\text { Squares }\end{array}$ & Df & $\begin{array}{c}\text { Mean } \\
\text { Square }\end{array}$ & F & Sig. \\
\hline \multirow{3}{*}{1} & Regression & 110.394 & 5 & 22.079 & 277.610 & $.000^{\mathrm{b}}$ \\
\cline { 2 - 7 } & Residual & 42.311 & 532 & .080 & & \\
\cline { 2 - 7 } & Total & 152.704 & 537 & & & \\
\hline
\end{tabular}

a. Dependent Variable: Green Purchase Intentions

b. Predictors: (Constant), Green Advertising, Green Price, Green Product Availability, Green Product \& Brand and Eco-labels

Source: Prepared by Author

Table - 12: Coefficients ${ }^{\text {a }}$ (Enter Method) for regression analysis between Green Marketing Tools' and Green Purchase Intentions:

\begin{tabular}{|c|c|c|c|c|c|c|}
\hline & \multicolumn{2}{|c|}{$\begin{array}{c}\text { Unstandardized } \\
\text { Coefficients }\end{array}$} & \multirow{2}{*}{$\begin{array}{c}\begin{array}{c}\text { Standardized } \\
\text { Coefficients }\end{array} \\
\text { Beta }\end{array}$} & \multirow[t]{2}{*}{$\mathbf{t}$} & \multirow[t]{2}{*}{ Sig. } \\
\hline & & \multirow{2}{*}{$\begin{array}{c}\text { B } \\
.342\end{array}$} & \multirow{2}{*}{$\begin{array}{c}\text { Std. Error } \\
.118\end{array}$} & & & \\
\hline \multirow{6}{*}{1} & Model & & & & 2.889 & .004 \\
\hline & Green Advertising & .622 & .031 & .635 & 20.050 & .000 \\
\hline & \multirow{2}{*}{\begin{tabular}{|l|} 
Green Price \\
Green Product Availability
\end{tabular}} & .121 & .017 & .178 & 7.287 & .000 \\
\hline & & .097 & .026 & .131 & 3.747 & .000 \\
\hline & Green Product \& Brand & .104 & .017 & .163 & 6.223 & .000 \\
\hline & Eco-labels & .141 & .025 & .180 & 8.605 & .000 \\
\hline
\end{tabular}

a. Dependent Variable: Green Purchase Intentions

Source: Prepared by Author

Table - 13: Pair-wise (bivariate) correlations of derived factors of Green Marketing Tools' with consumers' Green Buying Behaviour (i.e. Green Purchase Behaviour) 
ELK ASIA PACIFIC JOURNAL OF MARKETING \& RETAIL MANAGEMENT

ISSN 2349-2317 (Online); DOI: 10.16962/EAPJMRM/issn. 2349-2317/2018; Volume 9 Issue 4 (2018)

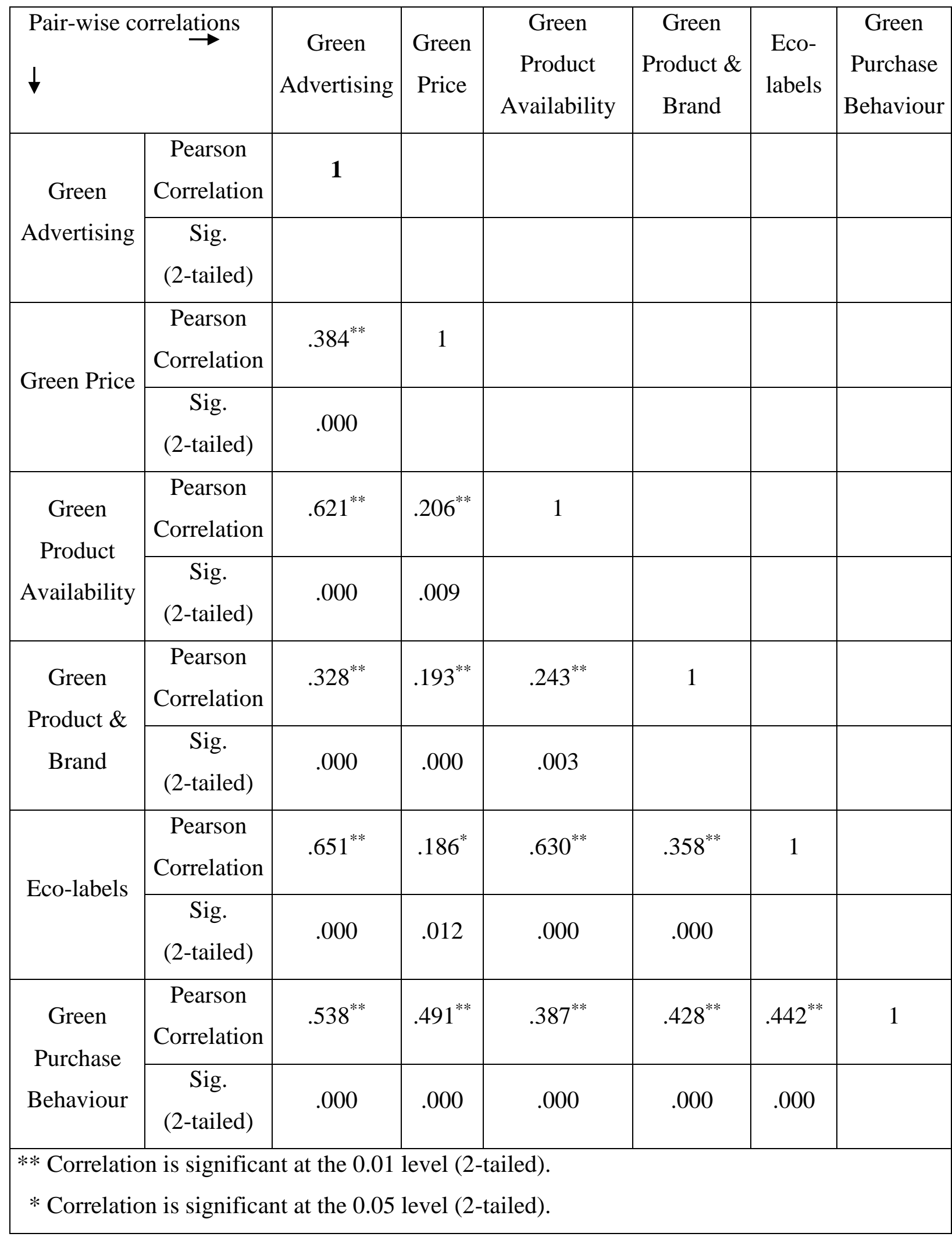

Source: Prepared by Author 
Table - 14: Model Summary ${ }^{\mathrm{b}}$ (Enter Method) for regression analysis between Green Marketing Tools' and consumers' Green Buying Behaviour (i.e. Green Purchase Behaviour):

\begin{tabular}{|c|c|c|c|c|c|c|c|c|c|}
\hline Model & $\mathbf{R}$ & $\mathbf{R}$ & Adjusted & Std. Error & \multicolumn{5}{|c|}{ Change Statistics } \\
\cline { 5 - 10 } & & Square & R Square & $\begin{array}{c}\text { of the } \\
\text { Estimate }\end{array}$ & $\begin{array}{c}\text { R Square } \\
\text { Change }\end{array}$ & $\begin{array}{c}\text { F } \\
\text { Change }\end{array}$ & df1 & df2 & $\begin{array}{c}\text { Sig. F } \\
\text { Change }\end{array}$ \\
\hline 1 & $.771^{\mathrm{a}}$ & .594 & .590 & .33410 & .594 & 155.649 & 5 & 532 & .000 \\
\hline
\end{tabular}

a. Predictors: (Constant), Green Advertising, Green Price, Green Product Availability, Green Product \& Brand and Eco-labels

b. Dependent Variable: Green Purchase Behaviour

Source: Prepared by Author

Table - 15: ANOVA $^{\text {a }}$ (Enter Method) for regression analysis between Green Marketing Tools' and consumers' Green Buying Behaviour (i.e. Green Purchase Behaviour):

\begin{tabular}{|c|l|c|c|c|c|c|}
\hline \multicolumn{2}{|c|}{ Model } & $\begin{array}{c}\text { Sum of } \\
\text { Squares }\end{array}$ & Df & $\begin{array}{c}\text { Mean } \\
\text { Square }\end{array}$ & F & Sig. \\
\hline \multirow{3}{*}{1} & Regression & 86.872 & 5 & 17.374 & 155.649 & $.000^{\mathrm{b}}$ \\
\cline { 2 - 7 } & Residual & 59.385 & 532 & .112 & & \\
\cline { 2 - 7 } & Total & 146.257 & 537 & & & \\
\hline \multirow{2}{*}{} & & &
\end{tabular}

a. Dependent Variable: Green Purchase Behaviour

b. Predictors: (Constant), Green Advertising, Green Price, Green Product Availability, Green Product \& Brand and Eco-labels

Source: Prepared by Author

Table - 16: Coefficients ${ }^{\text {a }}$ (Enter Method) for regression analysis between Green Marketing Tools' and consumers' Green Buying Behaviour (i.e. Green Purchase Behaviour):

\begin{tabular}{|c|c|c|c|c|c|}
\hline \multirow{2}{*}{ Model } & \multicolumn{2}{|c|}{$\begin{array}{c}\text { Unstandardized } \\
\text { Coefficients }\end{array}$} & $\begin{array}{c}\text { Standardized } \\
\text { Coefficients }\end{array}$ & T & Sig. \\
\cline { 2 - 4 } & B & Std. Error & Beta & & \\
\hline
\end{tabular}


ISSN 2349-2317 (Online); DOI: 10.16962/EAPJMRM/issn. 2349-2317/2018; Volume 9 Issue 4 (2018)

\begin{tabular}{|l|l|c|c|c|c|c|}
\hline & (Constant) & 1.257 & .140 & & 8.966 & .000 \\
\hline \multirow{3}{*}{1} & Green Advertising & .455 & .020 & .726 & 22.907 & .000 \\
\cline { 2 - 7 } & Green Price & .216 & .037 & .225 & 5.871 & .000 \\
\cline { 2 - 7 } & Green Product Availability & .099 & .031 & .133 & 3.128 & .002 \\
\cline { 2 - 7 } & Green Product \& Brand & .111 & .020 & .152 & 4.205 & .000 \\
\cline { 2 - 7 } & Eco-labels & .134 & .030 & .176 & 4.914 & .000 \\
\hline \multirow{2}{*}{$*$}
\end{tabular}

a. Dependent Variable: Green Purchase Behaviour

Source: Prepared by Author

Table - 17: Model Summary ${ }^{\mathrm{b}}$ (Enter Method) for regression analysis between Green

Purchase Intentions and Green Buying Behaviour (i.e. Green Purchase Behaviour):

\begin{tabular}{|c|c|c|c|c|c|c|c|c|c|}
\hline Model & $\mathbf{R}$ & $\mathbf{R}$ & Adjusted & Std. Error & \multicolumn{5}{|c|}{ Change Statistics } \\
\cline { 5 - 10 } & & Square & R Square & $\begin{array}{c}\text { of the } \\
\text { Estimate }\end{array}$ & $\begin{array}{c}\text { R Square } \\
\text { Change }\end{array}$ & $\begin{array}{c}\text { F } \\
\text { Change }\end{array}$ & df1 & df2 & $\begin{array}{c}\text { Sig. F } \\
\text { Change }\end{array}$ \\
\hline 1 & $.646^{\mathrm{a}}$ & .419 & .416 & .31847 & .419 & 383.928 & 1 & 536 & .000 \\
\hline
\end{tabular}

a. Predictors: (Constant), Green Purchase Intentions

b. Dependent Variable: Green Purchase Behaviour

Source: Prepared by Author

Table - 18: ANOVA $^{\text {a }}$ (Enter Method) for regression analysis between Green Marketing

Tools' and consumers' Green Buying Behaviour (i.e. Green Purchase Behaviour):

\begin{tabular}{|c|c|c|c|c|c|c|}
\hline \multicolumn{2}{|c|}{ Model } & $\begin{array}{c}\text { Sum of } \\
\text { Squares }\end{array}$ & Df & $\begin{array}{c}\text { Mean } \\
\text { Square }\end{array}$ & F & Sig. \\
\hline \multirow{3}{*}{1} & Regression & 38.939 & 1 & 38.939 & 383.928 & $.000^{\mathrm{b}}$ \\
\cline { 2 - 7 } & Residual & 54.363 & 536 & .101 & & \\
\cline { 2 - 7 } & Total & 93.302 & 537 & & & \\
\hline
\end{tabular}

Source: Prepared by Author 
ISSN 2349-2317 (Online); DOI: 10.16962/EAPJMRM/issn. 2349-2317/2018; Volume 9 Issue 4 (2018)

Table - 19: Coefficients ${ }^{\text {a }}$ (Enter Method) for regression analysis between Green Purchase Intentions and Green Buying Behaviour (i.e. Green Purchase Behaviour):

\begin{tabular}{|c|c|c|c|c|c|}
\hline \multirow[t]{2}{*}{ Model } & \multicolumn{2}{|c|}{$\begin{array}{c}\text { Unstandardized } \\
\text { Coefficients }\end{array}$} & $\begin{array}{c}\text { Standardized } \\
\text { Coefficients }\end{array}$ & $\mathbf{T}$ & Sig. \\
\hline & B & Std. Error & Beta & & \\
\hline (Constant) & 1.060 & .113 & & 9.365 & .000 \\
\hline Green Purchase Intentions & .718 & .037 & .646 & 19.594 & .000 \\
\hline
\end{tabular}

a. Dependent Variable: Green Purchase Behaviour (Green Purchase Behaviour)

Source: Prepared by Author

Table - 20: Mediation effect of Green Purchase Intentions between the predictors and the criterion variable:

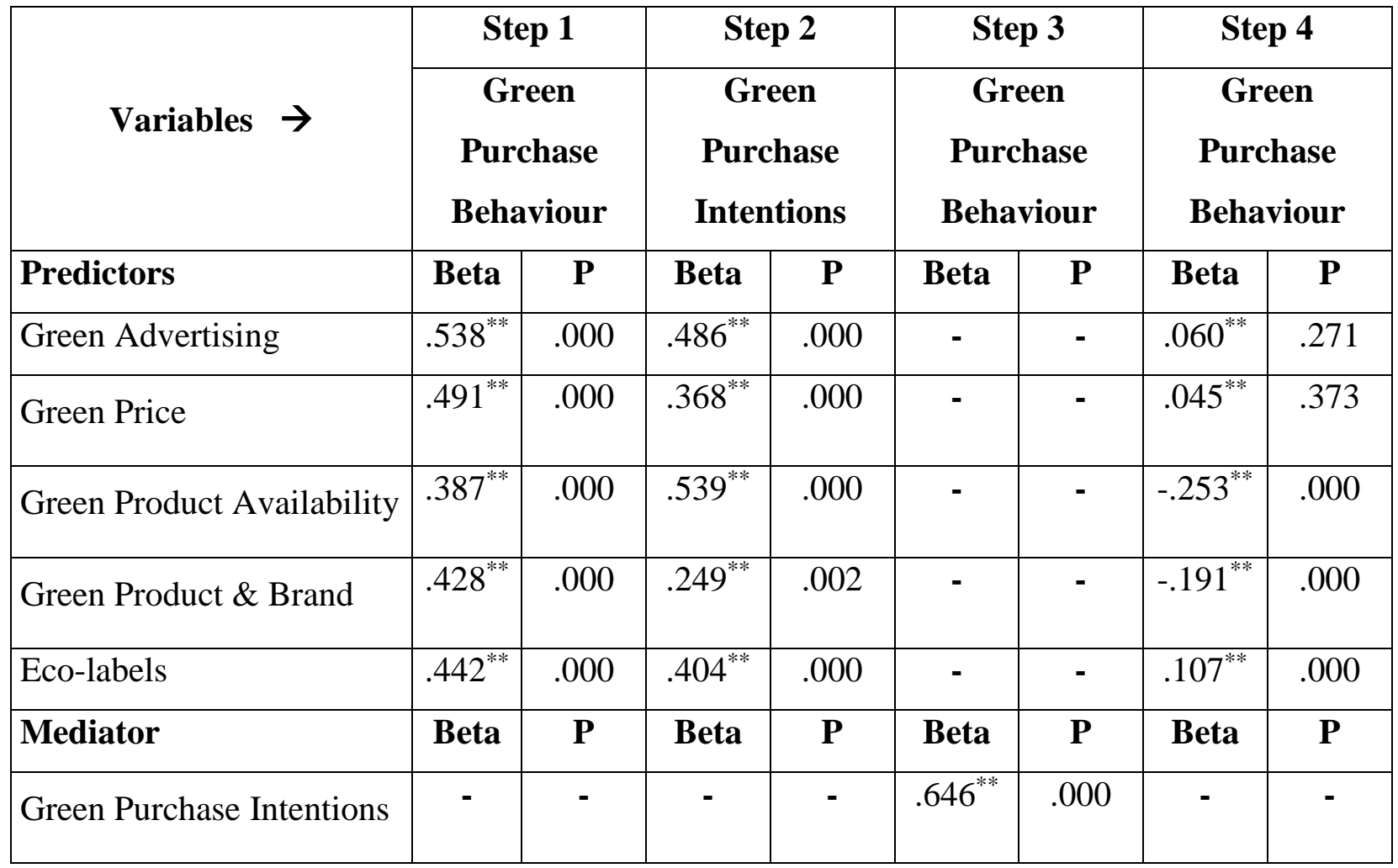

Source: Prepared by Author 
ELK ASIA PACIFIC JOURNAL OF MARKETING \& RETAIL MANAGEMENT

ISSN 2349-2317 (Online); DOI: 10.16962/EAPJMRM/issn. 2349-2317/2018; Volume 9 Issue 4 (2018) 